\title{
Seasonal feeding plasticity can facilitate coexistence of dominant omnivores in Neotropical streams
}

\author{
Mayara P. Neves $(\mathbb{D} \cdot$ Pavel Kratina $(\mathbb{D} \cdot$ Rosilene L. Delariva · J. Iwan Jones • \\ Clarice B. Fialho
}

Received: 3 September 2020/ Accepted: 17 February 2021/Published online: 6 March 2021

(C) The Author(s) 2021

\begin{abstract}
Coexistence of ecomorphologically similar species in diverse Neotropical ecosystems has been a focus of long-term debate among ecologists and evolutionary biologists. Such coexistence can be promoted by trophic plasticity and seasonal changes in omnivorous feeding. We combined stomach content and stable isotope analyses to determine how seasonal variation in resource availability influences the consumption and assimilation of resources by two syntopic fish species, Psalidodon aff. gymnodontus and $P$. bifasciatus, in the Lower Iguaçu basin. We also tested the impact of seasonality on trophic niche
\end{abstract}

Supplementary Information The online version contains supplementary material available at https://doi.org/10.1007/ s11160-021-09648-w.

M. P. Neves $(\bowtie) \cdot$ C. B. Fialho

Programa de Pós-Graduação em Biologia Animal,

Departamento de Zoologia, Instituto de Biociências,

Universidade Federal do Rio Grande do Sul, Porto Alegre,

RS, Brazil

e-mail: mayara-nevesbio@hotmail.com

M. P. Neves · P. Kratina $(\bowtie) \cdot$ J. I. Jones

School of Biological and Chemical Sciences, Queen Mary

University of London, London, UK

e-mail: p.kratina@qmul.ac.uk

\section{R. L. Delariva}

Programa de Pós-Graduação em Conservação e Manejo de Recursos Naturais, Centro de Ciências Biológicas e da Saúde, Universidade Estadual do Oeste do Paraná,

Cascavel, PR, Brazil breadth and diet overlap of these two dominant omnivores. Seasonal changes in resource availability strongly influenced the consumption and assimilation of resources by the two fish species. Both species exhibited high levels of omnivory, characterized by high diversity of allochthonous resources in the wet season. Terrestrial invertebrates were the main component of diet during this season. However, in the dry season, both species reduced their isotopic niches, indicating diet specialization. High diet overlap was observed in both seasons, but the isotopic niche overlap was smaller in the dry season. Substantial reduction in the isotopic niche of $P$. bifascistus and a shift toward aquatic invertebrates can facilitate coexistence during this season of resource shortage. Feeding plasticity allows omnivorous fish to adjust their trophic niches according to seasonality, promoting the exploitation of different resources during periods of greater resource diversity. This seasonal variation could be an important mechanism that contributes to the resource partitioning and coexistence of dominant omnivores in Neotropical streams.

Keywords Neotropical fish · Omnivory · Species coexistence $\cdot$ Stable isotope analysis $\cdot$ Trophic niche 


\section{Introduction}

The ecological mechanisms that enable the coexistence of similar species in diverse Neotropical communities are not fully understood, but such coexistence can be facilitated by high trophic plasticity, which can be favored by subtle morphological differences, and changes in omnivorous feeding during periods of food shortage (Chase and Leibold 2003). Omnivory is a widespread feeding strategy where consumers feed at multiple trophic levels (Pimm and Lawton 1978; Pimm 1982; Pimm et al. 1991; Kratina et al. 2012). Although it generally refers to feeding on both animals and plants, omnivory also includes cases where an intermediate consumer and its predator compete for shared resources (Polis et al. 1989; Holt and Polis 1997; Ingram et al. 2012). However, the effects of temporal changes in the diet of sympatric omnivores that utilize the same resources remain unclear, especially in Neotropical streams. Variation in diet breath could be influenced by seasonal changes in precipitation, temperature and nutrient concentrations, which all govern the availability and diversity of food resources (Lowe-McConnell 1999; Abujanra et al. 2009; Ruiz-Cooley et al. 2017). A shift in trophic niche away from possible competitors during periods of low availability of resources may facilitate coexistence of omnivorous species, and reduce the risk of local extinctions (Ingram et al. 2012; Pereira et al. 2010; Wooton 2017).

Omnivorous fish are common consumers in freshwater ecosystems (Barros et al. 2017; Garcia et al. 2016; Costa-Pereira et al. 2017; Silva et al. 2017), but ecologists still seek to understand how seasonality influences their trophic niches, and, consequently, the diversity of ecomorphologically similar species. Competition theory postulates that intraspecific competition during seasons with a shortage of food is dampened by the narrowing of trophic niches and a reduction in diet overlap among species (Pianka 1974; Schoner 1974). On the other hand, omnivores can expand their diet in seasons with high resource availability, resulting in increased overlap of trophic niches among species. However, empirical findings indicate that not all syntopic, congeneric species can expand their diet breath in periods of greater diversity and abundance of resources (Correa and Winemiller 2014; Silva et al. 2017; Neves et al. 2018a, b). This may be related to the traits and food preferences of species, and thus be of further assistance to understanding species coexistence (Chesson 2000; Walker et al. 2013; Alves et al. 2020).

Omnivorous fish in Neotropical streams experience a season with high resource abundance, followed by a season of resources shortages, corresponding to the wet and dry seasons respectively (Pujarra et al. 2017; Quirino et al. 2017). Continuous precipitation during the wet season increases water flow, hindering the establishment of the benthic invertebrate community (Pujarra et al. 2017) and increasing inputs of terrestrial resources (Lisboa et al. 2015; Tonin et al. 2017). The allochthonous subsidies are substantially reduced during the dry season, when aquatic consumers rely predominantly on autochthonous resources (Soares et al. 2013; Correa and Winemiller 2014). It has been hypothesized that these strong seasonal differences in resource availability and composition are responsible for the dominance of omnivorous fish species in the tropics (González-Bergonzoni et al. 2012; Silva et al. 2017). Omnivorous feeding in the tropics may be further promoted by a high abundance of primary producers and high environmental temperatures (González-Bergonzoni et al. 2012).

Omnivory in Neotropical streams is mainly represented by small fish species from the family Characidae. Among these, Psalidodon and Astyanax are highly diverse genera with a wide geographical distribution (Eschmeyer et al. 2016; Rossini et al. 2016; Bonato et al. 2017; Silva et al. 2017; Terán et al. 2020). Although species of these genera are considered to be omnivores (Baumgartner et al. 2012), responses in their feeding and resource assimilation to seasonal changes are poorly understood. Recent works have suggested that seasonal variation in precipitation alters the availability of resources in floodplains, lakes and rivers, which, in turn, promotes changes in trophic niches of characid fish (Quirino et al. 2015; CostaPereira et al. 2017; Silva et al. 2017; Neves et al. 2018a, b). Thus, a greater mechanistic understanding of how seasonal changes in resource use affect the trophic ecology of these fish could provide new insights about the coexistence of diverse communities of Neotropical consumers.

In the Iguaçu river basin (Brazil), there are 12 species of the genera Astyanax and Psalidodon (Haluch and Abilhoa 2005; Abilhoa and Duboc 2007; Pavanelli and Oliveira 2009; Baumgartner et al. 2012; Ingenito and Duboc 2014); with 
Psalidodon bifasciatus (Garavello and Sampaio 2010) and Psalidodon gymnodontus (Eigenmann 1911) among the most common and dominant species (Baumgartner et al. 2012; Neves et al. 2015; Larentis et al. 2016; Delariva et al. 2018; Baldasso et al. 2019). These species were recently relocated to the genus Psalidodon by Terán et al. (2020), previously being recognized as Astyanax gymnodontus and Astyanax bifasciatus. This basin has a high number of endemic tetra fish species but the overall diversity of fish fauna is low in comparison with other basins (Zawadzki et al. 1999; Baumgartner et al. 2012). This region is characterized by distinct dry and wet seasons, and represents a suitable model system to test hypotheses about the trophic ecology and coexistence of congeneric omnivorous fish.

Herein, we investigated seasonal variation in the trophic ecology of the dominant syntopic omnivores, $P$. aff. gymnodontus and $P$. bifasciatus, in a stream of the Lower Iguaçu river basin. We combined stomach content and stable isotope analyses (Nielsen et al. 2018) to test how seasonal changes in resource availability and diversity alter: (1) the consumption and assimilation of resources; (2) the trophic position; (3) the trophic niche breadths and niche overlap of both species. We hypothesized a shift in resource consumption and assimilation from mainly aquatic resources in the dry season, to mainly terrestrial resources during the wet season. Based on the predictions of competition theory (Pianka 1974; Schoner 1974), we expected wider trophic niches, higher niche overlap and a greater degree of omnivory in the wet season due to the high input of abundant and diverse allochthonous resources. In contrast, we expected reduced trophic niches in the dry season characterized by reduced resource diversity, and dominance of autochthonous resources. We also hypothesized that both species would feed at higher trophic positions during the dry season, due to a diet comprising mainly animal resources. Finally, we expected both species to share food resources during the period of greatest resource diversity (wet season) and to focus their diet on preferred resources during the period of resource scarcity (dry season). Such information would improve our understanding of the mechanisms that facilitate the coexistence of ecomorphologically similar omnivores in diverse Neotropical ecosystems.

\section{Methods}

Study area

The Lower Iguaçu river basin is an important hotspot for biodiversity (Abell et al. 2008). In this basin, the Iguaçu National Park protects one of the few remaining areas of Atlantic Rain Forest. About $70 \%$ of the fish fauna is considered endemic, comprising small and medium sized species, mainly belonging to the genera Astyanax and Psalidodon (Baumgartner et al. 2012; Terán et al. 2020). Despite its importance, the Lower Iguaçu river basin is threatened by intensive soybean and corn agriculture.

We studied seasonal differences in the trophic ecology of two dominant syntopic species of the genus Psalidodon in the Arquimedes stream (25 9'10.25 “ $\mathrm{S}$ $\left.53^{\circ} 16^{\prime} 41.86^{\prime \prime} \mathrm{W}\right)$. This third-order headwater stream ( $\sim 700 \mathrm{~m}$ altitude) is approximately $4 \mathrm{~m}$ wide and between 0.20 and $0.8 \mathrm{~m}$ deep. About $66 \%$ of the stream basin area is covered with native vegetation, and surface geology is composed mainly of sand, pebbles and gravel (Neves et al. 2018a, b). Basal resources fueling the stream food webs are dominated by native terrestrial vegetation and aquatic periphyton associated with stones. The climate of this region is humid subtropical (Köppen 1936; Baumgartner et al. 2012), and characterized by cold and dry winters, followed by hot and humid summers (Baumgartner et al. 2012; Fig. S1). Whereas increased precipitation in the wet season leads to abrupt changes in stream water flow, prolonged periods of flooding are not commonly observed like in floodplains. During this period there is also reduced availability of autochthonous resources, because the high flows associated with precipitation hinder the establishment of the benthic communities in these headwater streams (Pujarra et al. 2017).

\section{Field sampling}

We performed two field sampling campaigns during the middle of the dry (July) and the wet (December) seasons of 2017 (Fig. S1). We collected fish from $50 \mathrm{~m}$ stream reaches using depletion electrofishing with three passes. We highlight that in both seasons, sampling was standardized with the same effort to capture. During this sampling period, $P$. aff. gymnodontus and $P$. bifasciatus were the only species 
of Characidae and the most abundant fish species detected (68\% of the total number of individuals). After identification, all specimens were measured and weighed. Before processing for analysis of stomach contents, all specimens were anesthetized in eugenol, fixed in 10\% formaldehyde and preserved in $70 \%$ alcohol. For stable isotope analysis, adult specimens of each species were immediately euthanized via spinal section and stored on ice for further processing in the laboratory. The fish samples were collected with authorization from the Instituto Chico Mendes de Conservação da Biodiversidade (ICMBio) (license numbers 30182, 25,039-1) and approved by the Ethics Committee on Animal Use of the Universidade Federal do Rio Grande do Sul (CEUA - 32.734). Voucher specimens were deposited in the fish collection at the Departamento de Zoologia, Universidade Federal do Rio Grande do Sul (P. aff. gymnodontus, UFRGS 25.725; $P$. bifasciatus, UFRGS 26.235).

During the two fish sampling campaigns, we also collected aquatic and terrestrial basal resources and invertebrate prey in the same $50 \mathrm{~m}$ stream reaches where fish were collected. Basal resources included terrestrial leaves and seeds from live plants in the riparian vegetation, aquatic biofilm and sedimentary organic matter (SOM). We stored vegetation resources in plastic bags. We sampled biofilm by scraping and washing rocks with distilled water. We also manually sampled SOM from sediment deposits in the three random sections of the streams by gently removing sediment deposits and stored in plastic bottles. We stored all samples of SOM and biofilm in plastic bottles. We sampled aquatic invertebrates (Trichoptera, Hemiptera, Coleoptera, Megaloptera, Odonata, and Aeglidae) manually, using a kick net method. We also used entomological nets to sample terrestrial invertebrates (Coleoptera, Odonata, Hymenoptera, Orthoptera, Diptera, and Oligochaeta) in riparian vegetation around the edges of the stream. We stored both aquatic and terrestrial invertebrate samples in Eppendorf tubes. We froze all fish samples, basal resources and prey individuals at $-20{ }^{\circ} \mathrm{C}$ until processing.

To determine the seasonal differences in the availability of aquatic macroinvertebrate prey, in the two fish sampling campaigns, we randomly collected Surber samples $\left(0.04 \mathrm{~m}^{2}\right.$ and $200 \mu \mathrm{m}$ of mesh size, five minutes' duration) from three different substrates across the stream reaches $(50 \mathrm{~m})$ concomitantly with the fish sampling (in July and December 2017). We rinsed the samples with running water in a set of sieves of different mesh sizes $(2.0,1.0$ and $0.2 \mathrm{~mm}$ ) and preserved the macroinvertebrate samples in $70 \%$ ethanol for later enumeration and identification under a stereoscopic microscope (Opton TIM-2B WF10X). We estimated the potential prey availability as the number of macroinvertebrate individuals found per square meter of stream (density). For this, we divided the number of collected individuals by the Surber sampler area $\left(0.04 \mathrm{~m}^{2}\right)$.

\section{Laboratory procedures}

We inspected the gonads of all sampled fish according to the methodology proposed by Vazzoler (1996) and we selected only adult specimens with mature gonads for further analyses. For stomach content analysis, we used a total of 138 fish specimens of similar standard lengths (SL) for both species. In the dry season, we analyzed 60 specimens of $P$. aff. gymnodontus (mean and standard deviation SL: $8.73 \pm 1.24 \mathrm{~cm}$ ), and 32 specimens of $P$. bifasciatus (SL: $7.80 \pm 1.24 \mathrm{~cm}$ ). In the wet season, we used 36 specimens of $P$. aff. gymnodontus (SL: $7.96 \pm 1.33 \mathrm{~cm}$ ), and 15 specimens of $P$. bifasciatus (SL: $6.56 \pm 1.33 \mathrm{~cm}$ ). We removed fish stomachs and used optical and stereoscopic microscopes (Opton TIM-2B WF10X) to identify the stomach contents to the lowest taxonomic resolution possible, using specific literature for algae (Bicudo and Bicudo 1970) and invertebrates (Mugnai et al. 2010). We quantified food items using the volumetric method (Hyslop 1980), with graduated test tubes and a glass counting plates (Hellawell and Abel 1971). Detritus in the stomachs was considered as sedimentary organic matter (SOM) in different stages of decomposition, and mineral particles.

For stable isotope analysis, we analyzed a total of 40 fish specimens. The stomach contents of these specimens were also analyzed. In each season, we selected ten adult specimens of $P$. aff. gymnodontus (Dry: $10.54 \pm 0.69 \mathrm{~cm}$; Wet: $8.99 \pm 1.46 \mathrm{~cm}$ ) and ten adult specimens of $P$. bifasciatus (Dry: $8.27 \pm 1.34 \mathrm{~cm}$; Wet: $7.50 \pm 1.03 \mathrm{~cm}$ ). According to the Cucherousset and Villéger (2015), this sample number is enough to get a robust estimate of the isotopic niches of the species. We dissected samples of dorsal muscle tissue, washed them with distilled water, then lyophilized and homogenized them using 
a mortar and pestle. We also washed all basal resource and prey items with distilled water. We then lyophilized and homogenized aquatic and terrestrial invertebrates (separated by taxonomic groups), and basal resources. The small insects, including Ephemeroptera, Chironomidae, Coleoptera and Hymnoptera, were macerated as whole individuals. For shrimps and crabs (Aegla sp.), we extracted, lyophilized and macerated muscle tissues. We then stored all samples in $2 \mathrm{~mL}$ Eppendorf tubes, before weighing them into tin capsules $(1.6 \pm 0.2 \mathrm{mg}$ of dry animal tissue and $3.6 \pm 4.2 \mathrm{mg}$ for the basal resources samples). We analyzed the samples for nitrogen $\left({ }^{15} \mathrm{~N} /{ }^{14} \mathrm{~N}\right)$ and carbon $\left({ }^{13} \mathrm{C} /{ }^{12} \mathrm{C}\right)$ stable isotope ratios at the Center for Nuclear Energy in Agriculture (CENA) at the University of São Paulo, Brazil. To determine the stable isotope ratios, we used a mass spectrometer system in the continuous-flow (CFIRMS) mode with a Carlo Erba elemental analyzer (CHN 1110), coupled to a Delta Plus mass spectrometer (Thermo Scientific). We presented all values using the delta notation, which represents the deviation of stable isotope ratios $\left({ }^{13} \mathrm{C}:{ }^{12} \mathrm{C}\right.$ and $\left.{ }^{15} \mathrm{~N}:{ }^{14} \mathrm{~N}\right)$ from universal standards: $\mathrm{PDB}$ limestone for carbon and atmospheric nitrogen for nitrogen. We did not correct fish muscle $\delta^{13} \mathrm{C}$ for lipids because $\mathrm{C}: \mathrm{N}$ ratios were below 3.5 , indicating negligible lipid content in the samples (Hoffman et al. 2015).

\section{Statistical analysis}

\section{Stomach content analysis}

In order to test if diet differed in composition between the two species and two seasons, we applied a two-way PERMANOVA to a matrix of food items of individual fish (Table 1) using the Bray-Curtis index with 9999 permutations (Anderson 2001). To compare seasonal differences in intra- and inter-specific dietary niche breadth, we applied the permutational analysis of multivariate dispersions (PERMDISP, Anderson, 2006), where niche breadth was measured through the dispersion of the diet in space. A priori, we calculated the distance of a group from the centroid through principal coordinate analysis (PCoA), using the dissimilarity measure of Bray-Curtis and the volume matrix of food items (Table 1). The two groups represented the species and the seasons. To test the null hypothesis that niche breadth did not differ
Table 1 Food items consumed by $P$. aff. gymnodontus (Pag) and $P$. bifasciatus (Pbi) in Arquimedes stream, Lower Iguaçu river basin, southern Brazil, during the dry and wet seasons

\begin{tabular}{llllll}
\hline Season & Dry & & & Wet & \\
\cline { 2 - 3 } \cline { 5 - 6 } Species & Pag & Pbi & & Pag & Pbi \\
\hline Autochthonous & 19.7 & 13.4 & & 18.3 & 20.6 \\
Aeglidae & 1.3 & 1.1 & & 5.5 & \\
Ephemeroptera & 0.1 & & 2.1 & 0.8 \\
Plecoptera & $*$ & & 0.5 & 0.8 \\
Trichoptera (larvae) & 5.9 & 0.5 & & \\
Odonata (nymph) & 2.1 & 0.5 & & \\
Coleoptera (larvae) & 0.3 & & & 0.3 & 0.8 \\
Diptera (larvae and pupae) & 1.9 & 4.1 & & 1.6 & 0.5 \\
Lepidoptera (larvae and pupae) & 0.5 & 3.4 & 5.1 & \\
Aquatic insect remains & 5.4 & 3 & & 3.2 & 17.6 \\
Scales & 2.1 & 0.8 & $*$ & \\
Allochthonous & 73.7 & 46.9 & & 70.3 & 76.8 \\
Araneae & & & & 1.7 & \\
Hymenoptera & 2.2 & 0.3 & 12.1 & 12 \\
Auchenorrhyncha & 1.0 & & & \\
Terrestrial Coleoptera adult & 8.2 & 5.5 & 22.2 & 7.1 \\
Terrestrial Diptera adult & 3.8 & & & \\
Terrestrial Lepidoptera adult & 0.3 & & 3.1 & \\
Terrestrial insect remains & 1.4 & 0.8 & 2.5 & 0.4 \\
Leaf remains and seeds & 56.7 & 40.4 & & 28.7 & 57.3 \\
Undetermined & & & & \\
Detritus & 6.7 & 39.7 & & 11.3 & 2.6 \\
\hline
\end{tabular}

The asterisk indicates a contribution less than $0.1 \%$

among the groups, we calculated F-statistics to compare the mean distance of each sample with the median of the group. We determined the statistical significance from 9999 permutations of the residuals of least squares (Anderson 2006). We then performed post hoc pairwise comparisons using Tukey's Honest Significant Difference test. All statistical analyses were performed in $\mathrm{R}$, version 3.5.2 ( $\mathrm{R}$ Core Team 2019), using the vegan package (Oksanen et al. 2019).

To determine the dietary overlap between species in each season, we calculated the food overlap index (Pianka 1973) based on the volume matrix of food items (Table 1) using EcoSimR package version 0.1.0 (Gotelli et al. 2015). Following Grossman (1986), we defined overlap as low (0-0.39), intermediate $(0.4-0.6)$ or high $(0.61-1)$. We then used the null model with a RA3 algorithm to evaluate the 
significance of Pianka's index (Winemiller and Pianka 1990). We performed 9999 Monte Carlo randomizations that represented a null model, that we then compared with the data (mean niche overlap values for all group pairs). Whereas mean overlap that is significantly lower than expected by chance indicates food partitioning, values higher than those expected by chance indicates food sharing (Albrecht and Gotelli 2001; Bonato et al. 2018). The observed overlap was compared with the null model at a significance level $\alpha=0.05$ to evaluate if the observed pattern differed from the randomly simulated overlap values.

\section{Stable isotope analysis}

Turnover rate of animal tissues is an important consideration when interpreting temporal variation in dietary assimilation (Kaymak et al. 2015; Garcia et al. 2016; Oliveira et al. 2017). Turnover rate can be influenced by extrinsic factors such as temperature and salinity (Mont'Alverne et al. 2016) and intrinsic factors, including tissue type, body size, sexual maturity, and growth rate (Kaymak et al. 2015; Kambikambi et al. 2019), with turnover rates of approximately three months reported for fish muscle tissue (Buchheister and Latour 2010; Jardine et al. 2011). Considering the turnover rates for muscles tissue in small fish (Kaymak et al. 2015; Mont' Alverne et al. 2016; Kambikambi et al. 2019), we assumed that the isotopic ratios of adult fish collected in July reflected the assimilation of resources consumed since April (Fig. S1) and, therefore, represented the diet during the wet season. Similarly, the isotopic ratios of adult fish collected in December reflected the assimilation of food resources consumed since July (Fig. S1), representing the diet during the dry season. We tested whether carbon $\left(\delta^{13} \mathrm{C}\right)$ and nitrogen $\left(\delta^{15} \mathrm{~N}\right)$ stable isotope ratios differed between species, and between wet and dry seasons using two-way Analysis of Variance (ANOVA) in the car package (Fox and Weisberg 2019). Also, we used a one-way ANOVA to test for differences in density of aquatic macroinvertebrates between seasons. We assured that the assumptions of normality (Shapiro-Wilk test) and homoscedasticity (Levene's test) were met.

To estimate the trophic position of both fish species in each season, we applied Bayesian trophic positions measured in tRophicposition package (QuezadaRomegialli et al. 2019), considering 20,000 iterations and five Markov chains. As the model implementation considered a maximum of two different baselines, we pooled (1) biofilm, SOM, and terrestrial vegetation into a basal resource baseline and (2) aquatic and terrestrial invertebrates into a prey baseline. We then calculated pairwise comparisons among species and seasons to determine any differences in estimated trophic position.

Fractionation is a relevant point to estimate the trophic position and resource assimilation. Here, for fish, we used Trophic Discrimination Factors (TDF) of $1.3 \pm 0.3 \%$ for $\mathrm{C}$, and $2.9 \pm 0.32 \%$ for $\mathrm{N}$ (McCutchan et al. 2003). This enrichment is appropriate for muscle tissues of omnivorous fish that consume mixtures of plant and animal diet (McCutchan et al. 2003). We also considered specific TDF values for plant resources (Bastos et al. 2017). Here, we followed the method of Neres-Lima et al. (2016) and doubled the mean discrimination factor and the variability estimate (SD) by propagation of error $\left(\sqrt{ }\left(2 . \mathrm{SD}^{2}\right)\right.$, yielding the values $2.6 \pm 0.42 \%$ for $\mathrm{C}$, and $5.8 \pm 0.45 \%$ for $\mathrm{N}$.

To estimate the degree of omnivory and isotopic niche overlap between the two species in each season, we calculated the isotopic metrics proposed by Cucherousset and Villéger (2015). In order to quantify isotopic niche size for the two species, we used convex hull area to determine isotopic similarity and isotopic nestedness (Cucherousset and Villéger 2015). Isotopic similarity (ISim) is the ratio between the isotopic overlap of two species and the total volume that both species occupy in the stable isotope space (Villéger et al. 2011). However, this index can be influenced by differences in the size of the convex hull of the two groups of organisms. Therefore, isotopic nestedness (Ines) was used as a complementary measure, representing the ratio between the volume of the intersection and the minimal volume filled by a species. Ines ranges from 0 with no isotopic overlap to 1 when the group with the lowest isotopic richness fills a subset of the isotopic space filled by the group with the highest isotopic richness (Cucherousset and Villéger 2015). We inferred the degree of omnivory based on the variation in nitrogen $\left(\delta^{15} \mathrm{~N}\right)$ stable isotope ratios calculated as ISim and Ines, where large variation in $\delta^{15} \mathrm{~N}$ values indicates assimilation of resources from different trophic levels. This approach quantitatively estimates several aspects of isotopic diversity and provides abundance-weighted and unitless indices, 
which can be easily compared. These metrics proposed by Cucherousset and Villéger (2015) are mathematically independent of the number of organisms used in the calculation and they can account for the differences in population density or biomass.

To determine the relative contributions of different diet sources assimilated by $P$. aff. gymnodontus and $P$. bifasciatus in each season, we applied Bayesian stable isotope mixing models (Moore and Semmens 2008; Parnell et al. 2010) from the MixSIAR package (Stock and Semmens 2016a). We compared the relative contribution of four isotopically homogeneous diet categories (Table S2, Fig. S4): aquatic invertebrates (Odonata nymph, Hemiptera nymph, Trichoptera larvae, Megaloptera larvae, Coleoptera larvae, Aeglidae adult), terrestrial invertebrates (Hymenoptera, Orthoptera, Araneae, Oligochaeta, Coleoptera adult, Diptera adult, Odonata adult), aquatic biofilm and SOM, and terrestrial plants (Pteridophita, Spermatophyta). To prevent erroneously attributing food items that are not consumed by the fish, we used the stomach content data as initial information. Because isotopic composition of terrestrial plants was very different from the composition of fish consumers (Fig. S7), we performed the mixing model analyses with and without terrestrial plants and our final model were composed of aquatic and terrestrial invertebrates and SOM. Both analyses provided qualitatively similar results and showed little contribution of terrestrial plants to the diet of fish consumers (Table S5 and S6). Therefore, we present the analysis without terrestrial plants below. We fit the model with a Markov chain Monte Carlo sampling with number of chains $=3$; chain length $=100,000$; burn in $=50,000 ;$ thin $=50$, model 4 (Resid*Process) error structure (Stock and Semmens 2016b), and with "uninformative/generalist" prior in MixSIAR. A hierarchical Bayesian mixing model computes the effects of covariates (factors: species and seasons) when estimating food assimilation patterns by consumers (Semmens et al. 2009). Here, we used this approach to evaluate potential changes in the assimilation of basal food sources considering species and seasons (wet and dry) as fixed factors, with species nested with seasons. Together with the source isotope values, we included elemental carbon (\%C) and nitrogen $(\% \mathrm{~N})$ composition data as concentration dependence because the $\mathrm{C}$ and $\mathrm{N}$ composition of plant and animal resources can differ (Phillips et al. 2014).
We examined model convergence using diagnostic tests (Gelmin-Rubin, Heidelberger-Welch and Geweke) and trace plots.

To verify that the isotopic variability of consumers, after accounting for fractionation, fell within the variability of their assimilated resources (Phillips et al. 2014), we performed isotope mixing polygon simulations using the $s p$ (Pebesma and Bivand 2005; Bivand et al. 2013) and splancs (Rowlingson and Diggle 2017) packages. This method quantitatively determines the boundaries of possible source values in the $\delta^{13} \mathrm{C}-\delta^{15} \mathrm{~N}$ biplots that can explain the isotope mixture (Smith et al. 2013). When individual consumers are located outside the $95 \%$ mixing polygon region, they could not be confidently explained by the available food sources (Phillips et al. 2014). We determined that it was not necessary to remove any individual from the final isotope mixing models (Fig. S6).

\section{Results}

Stomach content analysis revealed that the main food items in the diets of both fish species were leaves, seeds, insects and detritus (comprising $99.3 \%$ of all diet, Fig. 1, Table 1). As predicted, seasonal changes in resource availability and diversity altered the consumption and assimilation of resources, the trophic niche breadths and the niche overlap of both species. There were significant differences in the diet of the two species (Pseud-F $=2.24, p=0.029$ ), and between the dry and wet season (Pseud-F $=2.77, p=0.003$ ), with a significant interaction between species and season (Pseud-F $=2.27, p=0.003$ ). In the dry season, the stomach content of $P$. aff. gymnodontus consisted mostly of leaves, seeds $(56.7 \%)$ and terrestrial insects (17\%), whereas the stomach content of $P$. bifasciatus consisted mostly of leaves, seeds (40.4\%) and detritus (39.7\%). In the wet season, the stomach content of $P$. aff. gymnodontus consisted mostly of terrestrial insects (39.9\%), followed by leaves and seeds (28.7\%), whereas the stomach content of P. bifasciatus had a greater proportion of leaves and seeds (57.3\%), followed by aquatic $(20.5 \%)$ and terrestrial (19.5\%) insects (Fig. 1; Table 1).

The two fish species were significantly different in their trophic niche breadth in different seasons (ANOVA, $\mathrm{F}_{3,126}=4.74, p=0.004$; Fig. 2; Table 2). Psalidodon bifasciatus had a larger diet breadth during 


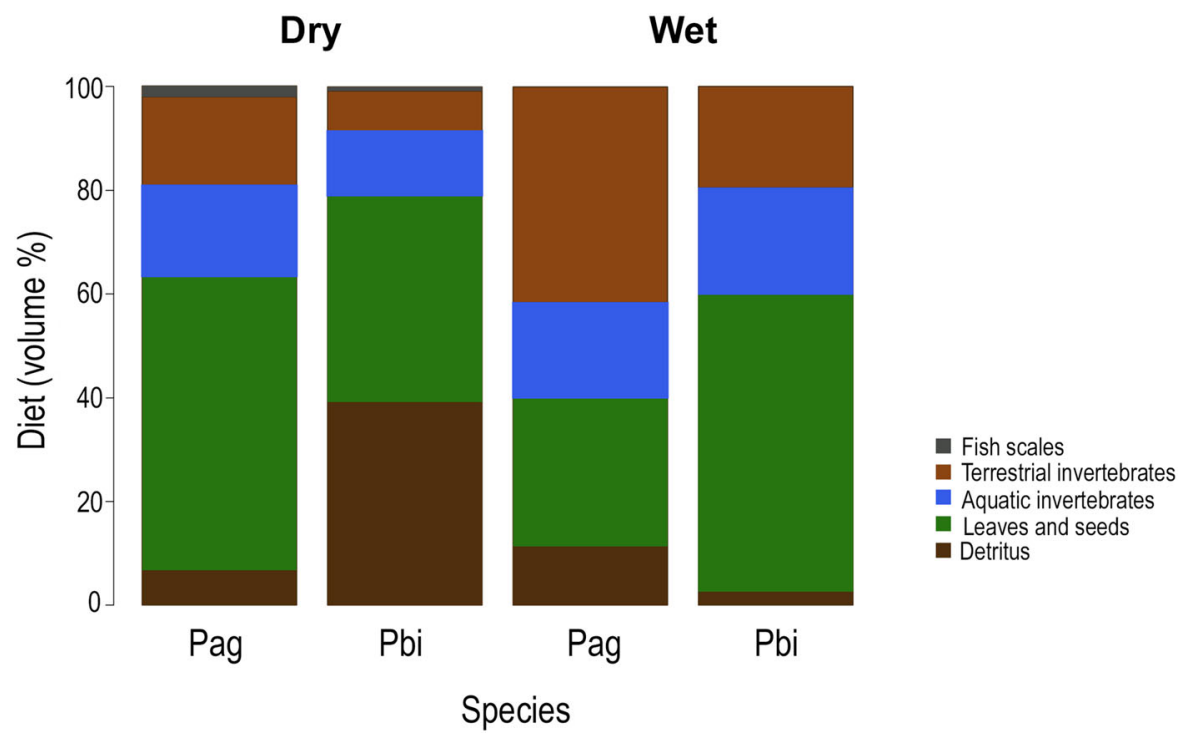

Fig. 1 The relative contribution (\%) of main food resources consumed by $P$. aff. gymnodontus (Pag) and P. bifasciatus (Pbi) during the dry and wet seasons. Proportions of resources in diet were estimated by volume from stomach content analysis

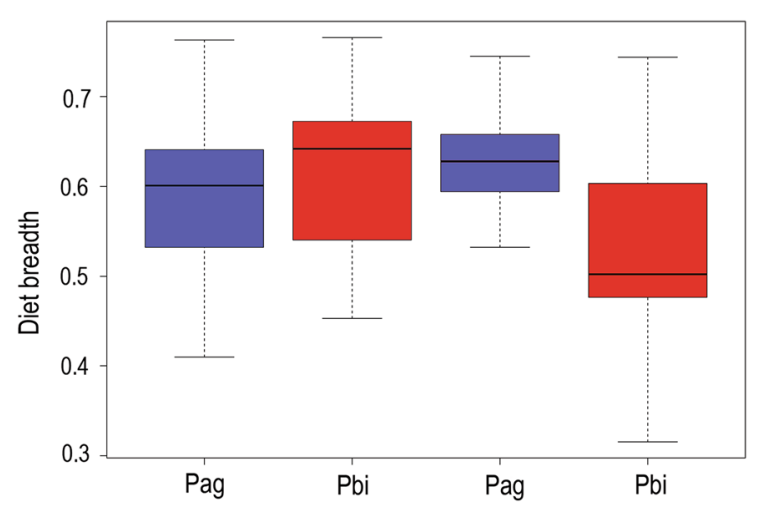

Fig. 2 Inter-seasonal differences in breadth of diet (measured as distance to centroid) of $P$. aff. gymnodontus (Pag) and $P$. bifasciatus (Pbi), assessed by permutational analysis of multivariate dispersions (PERMDISP). Box lower and upper endpoints represent the 25th and 75th quartiles, respectively and the horizontal bar inside each box represents median diet breadth (for $p$-values, see Table 2). Different letters indicate significant differences (Post-hoc test)

the dry season (PERMDISP, distance of centroid, $0.57)$, whereas $P$. aff. gymnodontus had a larger diet breath during the wet season $(0.60)$. There was relatively high diet overlap in both dry (Pianka's index $=0.74)$ and wet (Pianka's index $=0.81$ ) seasons. This high overlap in both seasons resulted from sharing leaves, seeds, detritus, aquatic insects, adult Coleoptera and Hymenoptera as resources (Fig. S3; Table S1).
Table 2 Pairwise comparisons of trophic niche breadth (PERMDISP, 9999 permutations) and trophic position (tRophicposition package) of $P$. aff. gymnodontus (Pag) and $P$. bifasciatus (Pbi) during the dry (D) and wet (W) seasons

\begin{tabular}{llcll}
\hline & \multicolumn{4}{l}{ Trophic Niche Breadth } \\
\cline { 2 - 5 } & PagD & PbiD & PagW & PbiW \\
\hline PagD & & 0.090 & $\mathbf{0 . 0 0 6}$ & 0.298 \\
PbiD & 0.097 & & 0.193 & $\mathbf{0 . 0 1 7}$ \\
PagW & $\mathbf{0 . 0 0 5}$ & 0.177 & & $\mathbf{0 . 0 0 1}$ \\
PbiW & 0.313 & $\mathbf{0 . 0 1 6}$ & 0.001 & \\
& Trophic position & & \\
PagD & \multicolumn{5}{l}{0.440} & 0.934 & 0.898 \\
PbiD & 0.560 & 0.941 & 0.903 \\
PagW & 0.066 & 0.059 & & 0.405 \\
PbiW & 0.102 & 0.097 & 0.595 & \\
\hline
\end{tabular}

Statistically significant $P$ values $(P \leq 0.05)$ are highlighted in bold

There was no difference in $\delta^{13} \mathrm{C}$ between species (ANOVA: $\mathrm{F}_{1,36}=2.28, p=0.14$ ), but there was a significant difference between the wet and dry seasons (ANOVA: $\mathrm{F}_{1,36}=8.25, p=0.007$ ), indicating that both fish species utilized different carbon sources in each season. There was no interaction effect between species and season (ANOVA: $\mathrm{F}_{1,36}=0.002$, $p=0.96)$. For both species, the $\delta^{13} \mathrm{C}$ had slightly 
higher values during the dry season $(-24.32$ to $20.57 \%$ o $)$ than the wet season $(-25.39$ to $-22.76 \%$ : Fig. S5). There was no difference in mean $\delta^{15} \mathrm{~N}$ between species (ANOVA: $\mathrm{F}_{1,36}=0.05, p=0.81$ ) or season (ANOVA: $\mathrm{F}_{1,36}=0.53, p=0.47$ ) and no significant interaction between species and season (ANOVA: $\mathrm{F}_{1,36}=1.59, p=0.21$ ). Contrary to our expectation, there was no significant difference in mean trophic position of both species between the dry season ( $P$. aff. gymnodontus: 3.34 ; P. bifasciatus: $3.29)$ and the wet season ( $P$. aff. gymnodontus: $2.55 ; P$. bifasciatus: 2.75; Fig. 3; Table 2). Both species contracted their isotopic niches during the dry season (cf. wet season), although this effect was more pronounced in $P$. bifasciatus (Fig. 4). There was higher isotopic similarity (0.36; Fig. 4; Table S4) and isotopic nestedness $(0.77)$ between the two species in the wet season compared with the dry season (ISim = 0.17 ; Ines $=0.70$ ), suggesting that both species expanded their isotopic niches and shared more similar resources in wet season. Major variation in ISim and Ines indicated a higher degree of omnivory during the wet season than in the dry season.

In agreement with our hypothesis, we observed a shift in resource consumption and assimilation from mainly aquatic resources in the dry season, to mainly terrestrial resources during the wet season. The

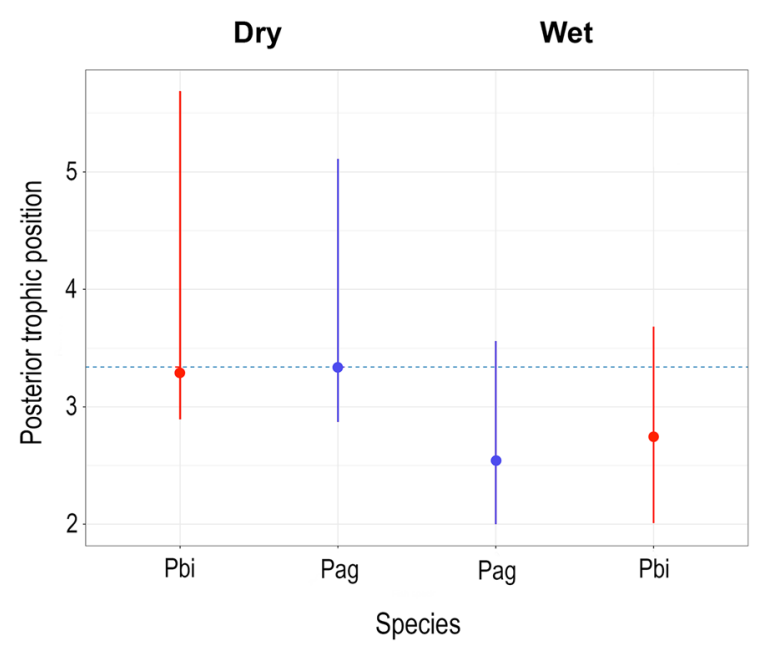

Fig. 3 Estimated trophic position (TP) of $P$. aff. gymnodontus (Pag) and P. bifasciatus (Pbi) during the dry and wet seasons. Species are ordered by modal TP values. Filled circles represent modes TP and the bars are $95 \%$ credibility interval of each posterior TP estimate. The horizontal blue dotted line shows maximum trophic position relative contribution of the main resource types to the diet of both fish species, inferred from the stable isotope mixing model, differed between the dry and wet season (Fig. 5; Table S6). In the dry season, $P$. bifasciatus assimilated mainly aquatic $(79 \pm 10 \%$, mean \pm SD) and terrestrial $(14 \pm 8 \%)$ invertebrates, while $P$. aff. gymnodontus assimilated aquatic $(67 \pm 13 \%)$ and terrestrial $(24 \pm 12 \%)$ invertebrates. In addition to a larger contribution of aquatic invertebrates to the diet of both species, there was a higher density of aquatic macroinvertebrates in the dry season than in wet season (ANOVA: $\mathrm{F}_{1,4}=12.16$, $p=0.025$; Fig. S2), suggesting increased availability. In the wet season, when availability of aquatic macroinvertebrates was lower (Fig. S2), both fish species increased consumption and assimilation of terrestrial invertebrates. Psalidodon aff. gymnodontus assimilated the highest proportion of terrestrial invertebrates ( $68 \pm 19 \%$ of their total diet), together with a smaller proportion of aquatic invertebrates $(17 \pm 9 \%)$ and $\operatorname{SOM}(15 \pm 17 \%)$. Similarly, $P$. bifasciatus assimilated a great proportion of terrestrial invertebrates ( $59 \pm 19 \%$ of their total diet), a low proportion of aquatic invertebrates $(27 \pm 12 \%)$, and a similar proportion of SOM $(14 \pm 16 \%)$ as $P$. aff. gymnodontus.

\section{Discussion}

Seasonal changes strongly influenced the consumption and assimilation of resources by the two dominant fish species, altering the diet breadth and isotopic niche of both species, and the extent of isotopic overlap between them. In dry season, $P$. bifasciatus and $P$. aff. gymnodontus assimilated high proportions of aquatic invertebrates. In this season, the high availability of aquatic macroinvertebrates was associated with a narrowing of isotopic niches of both species and reduced isotopic niche overlap (ISim $=0.17$; Ines $=$ 0.70 ), indicating greater resource specialization. During the wet season, when Neotropical aquatic ecosystems are known to have an increased availability of terrestrial resources (Correa and Winemiller 2014; Lisboa et al. 2015; Tonin et al. 2017), both species assimilated high proportions of terrestrial invertebrates. In this season, both fish species amplified their isotopic niches, indicating a greater level of omnivory, and increased their isotopic niche overlap 


\section{Dry}

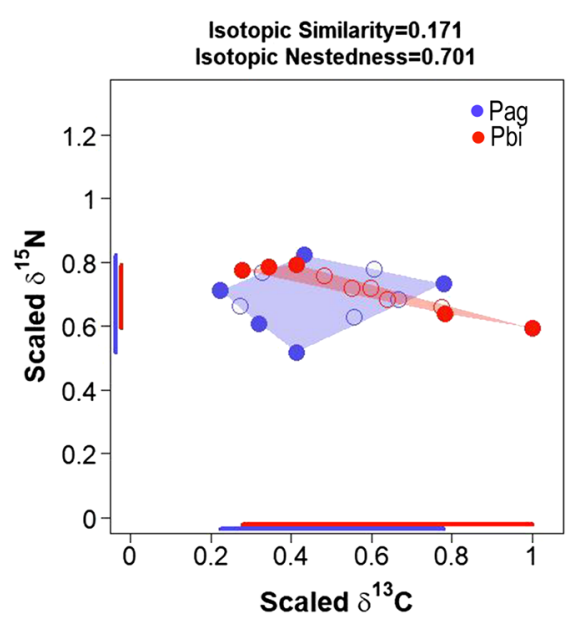

Fig. 4 Isotopic overlap between $P$. aff. gymnodontus (Pag) and $P$. bifasciatus $(\mathrm{Pbi})$ during the dry and wet seasons, illustrated in $\delta^{13} \mathrm{C}$ and $\delta^{15} \mathrm{~N}$ isotopic space. Isotopic overlap metrics were measured using the isotopic richness of the two species and the

$($ ISim $=0.36 ;$ Ines $=0.77)$. Although the stomach content analysis indicated high resource overlap in both seasons, the low overlap of isotopic niche may suggest species-specific differences in assimilation of consumed resources. These findings demonstrate that seasonal changes in resource availability and composition lead to partially differential resource use by two syntopic omnivores with otherwise widely overlapping trophic niches.

Although both species rely largely on terrestrial invertebrates during the wet season, our findings agree with previous studies from streams (Baldasso et al. 2019), rivers (Pini et al. 2019) and reservoirs (Delariva et al. 2013; Mise et al. 2013), suggesting higher consumption of terrestrial invertebrates by $P$. gymnodontus. Leaves and seeds were consumed in considerable proportions by both species (Fig. 1), but their assimilation into the fish tissues was very low (Fig. S7; Table S5). Similar high consumption but low assimilation of terrestrial plants has been observed in other tetra fish species (Bastos et al. 2017; Bonato et al. 2018). At least five factors could explain this apparent discrepancy between diet composition inferred from stomach contents and food assimilation inferred from stable isotope analysis. First, individual food items differ in their digestibility and nutritional quality (protein content; Bowen et al. 1995), and the two methods focus on trophic processes that operate

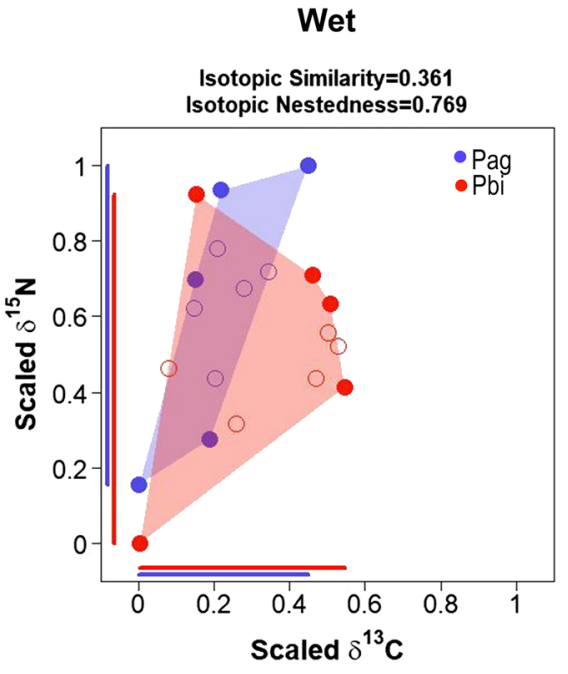

volume of isotopic space they shared. Isotopic overlap on each stable isotope axis is illustrated by the overlap of the colored segments symbolizing range of values for each species

on different time scales (Hyslop 1980; Bastos et al. 2017; Nielsen et al. 2018). Such differences in assimilation efficiency may be related to a lack of specialization in the digestive tract to facilitates the breakdown, digestion and assimilation of plant material (German et al. 2009; Pelster et al. 2015), and to the higher nutritional quality of animal prey (Gerking 1994). Second, the high intake of plant material may result from an opportunistic feeding strategy (Winemiller 1989), where consumers feed on the most available resources (in our case terrestrial plants) during shortages of other resources, even when these resources are not assimilated. Third, some studies suggest that plant material can be accidentally ingested when fish attempt to capture terrestrial insects on the water surface (Bastos et al. 2017; Bonato et al. 2018). However, the high proportion of ingested plant material suggests that accidental ingestion plays a minor role in this case. Finally, ingested plant material may include a biofilm, which is the main resource assimilated into fish tissues. The fifth reason for why fish may ingest but not assimilate plants is that this material is used to change the intestinal microbiota and to improve the intestinal transit and digestion time for more nutritious food (Baldo et al. 2015; Serra et al. 2019). The relative contribution of these factors remains a promising venue for future research. 

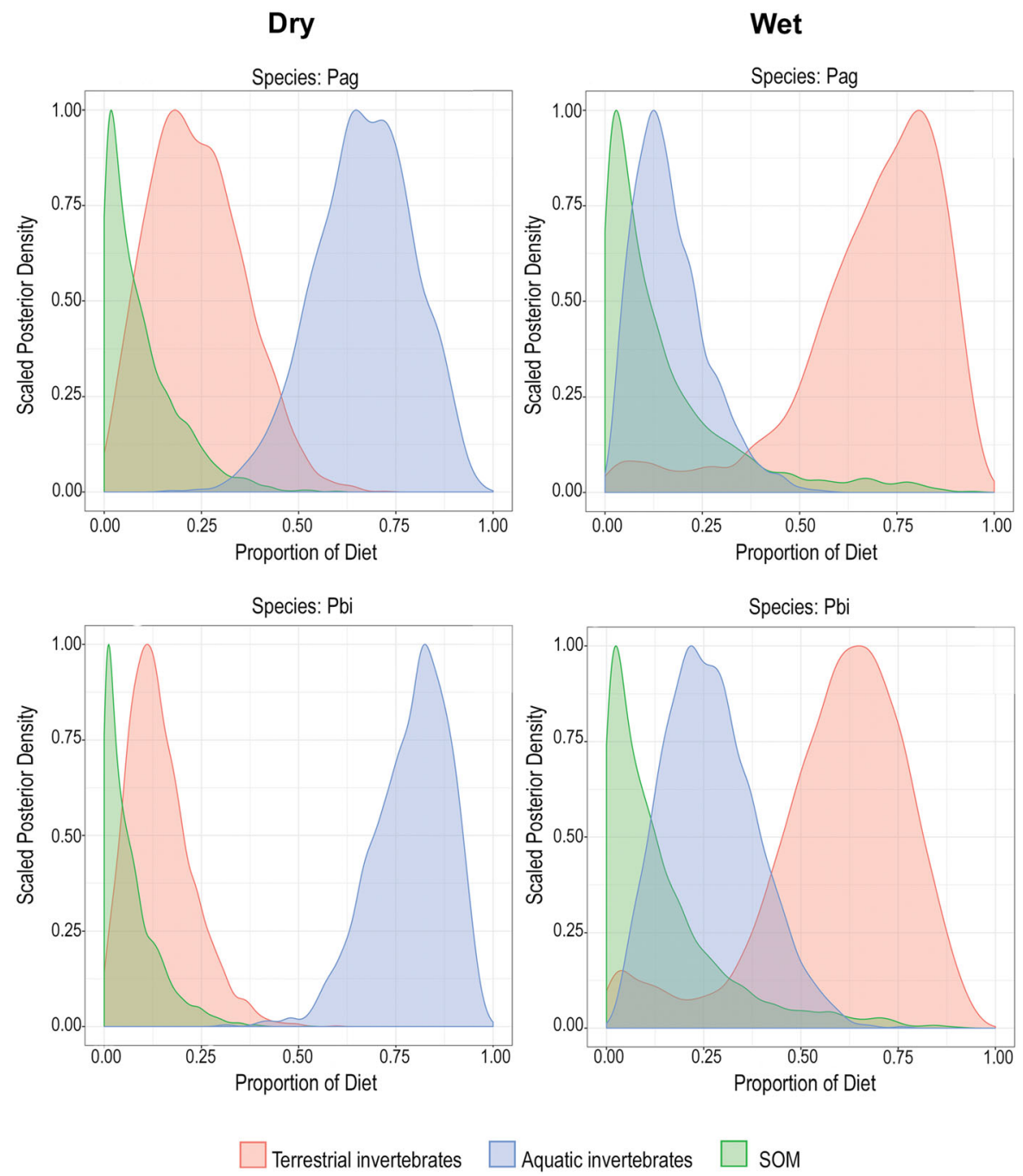

Fig. 5 Density plots depicting the relative isotopic contribution of food resources to $P$. aff. gymnodontus $(\mathrm{Pag}$ ) and $P$. bifasciatus (Pbi) during the dry and wet seasons. The relative diet

contributions were estimated using a MixSIAR Bayesian mixing model. SOM denotes sedimentary organic matter

In agreement with optimal foraging theory (Stephens and Krebs 1986; Schoener 1971), seasonal variation in resource supply may allow exploitation of preferred diet items during periods of high abundance. The greater feeding opportunities in the wet season have been associated with an expansion of trophic niches (Costa-Pereira et al. 2017), and here, with an increase in omnivory. During the wet season, $P$. aff. gymnodontus assimilated mainly terrestrial invertebrates, whereas $P$. bifasciatus assimilated terrestrial invertebrates, aquatic invertebrates and SOM. Similarly, high contributions of terrestrial invertebrates to the diets of aquatic consumers during periods of

greatest rainfall (wet season) have been recorded by studies in temperate environments (Perkins et al. 2008). Both species contracted their isotopic niches during the dry season ( $c f$. wet season), although this effect was more pronounced in P. bifasciatus. This supports the hypothesis that consumers have more specialized diets when their preferred resources are more abundant (Stephens and Krebs 1986; Perry and Pianka 1997). Moreover, our findings agree with observations from Neotropical ecosystems that not all fish species expand their niches in the rainy season or contract them during the dry season (Correa and Winemiller 2014; Silva et al. 2017). 
Variation in $\delta^{15} \mathrm{~N}$ across the time reflects differences in the degree of omnivory (Post and Takimoto 2007), the relative assimilation of nutrients (Hopkins and Ferguson 2012), or the protein content of consumed resources (Kelly and Martinez del Rio 2010). Here, the absence of significant differences in $\delta^{15} \mathrm{~N}$ resulted in similar trophic positions of the two species in both seasons. This indicates that, although the species differ in their carbon sources, both species maintained an omnivorous diet across seasons. Moreover, the similarity in the trophic position of species is likely related to the fact that the fish mainly assimilated animal resources in both seasons. Therefore, seasonal changes in the diet of both species alter their trophic niche breadth more than their trophic positions, which may have fundamental implications for how these species interact and compete for food resources.

Multiple mechanisms are likely to combine to facilitate coexistence in diverse tropical ecosystems (Vergnon et al. 2009). Stabilizing mechanisms act to reduce niche overlap through resource partitioning and spatio-temporal variation in environmental conditions (Chesson 2000). Equalizing mechanisms result from trade-offs that reduce fitness differences between potential competitors (Tilman 1990). Any two species must differ in both their requirements and impact on resource availability in order to locally coexist (Chase and Leibold 2003). In this study, the coexistence of two Psalidodon species was facilitated by seasonal variations in availability of resources and trophic plasticity of these omnivores, allowing them to partition resources. Both intrinsic (feeding preferences, species interactions) and extrinsic (environmental heterogeneity) changes over time and space determine the dynamics and coexistence of species (Chase and Leibold 2003; Hart et al. 2016). The interactions among species reflect trade-offs between their relative competitive abilities and their responses to these environmental variations (Wootton 1998). Similar isotopic composition of food sources in both seasons would indicate that the isotopic niche of consumers was reduced by preferential prey consumption (Table S2). Then, our findings suggest that the high abundance of aquatic insects in dry season (Fig. S2; Pujarra et al. 2017), might lead both species to specialize in these resources and increase the competitive pressure between them. Specially for $P$. bifasciatus, a shift toward feeding on aquatic invertebrates and a contraction of trophic niche by may be the mechanism that alleviates this pressure and facilitates coexistence during this season of resource shortage.

In conclusion, seasonal variation in environmental conditions influences trophic niche breadth and resource overlap of syntopic omnivorous fish species. These changes are germane for the detailed understanding of coexistence of phylogenetically related species in diverse Neotropical ecosystems. Trophic plasticity allows them to exploit alternative resources during periods of greater availability. To fully understand this trophic plasticity, future research should investigate how the food preferences of each species alleviate interspecific competition for shared resources. Then, we could infer if such shifts in resource supply can favor better competitors for aquatic resources during the dry season, but better competitors for terrestrial resources during the wet season. Considering future climate forecasts for South America (Chou et al., 2014), which indicate a drier and warmer climate (Chou et al. 2014; FIOCRUZ 2016), these findings highlight the need for a better mechanistic understanding of coexistence of species in changing freshwater ecosystems.

Acknowledgements We thank the Universidade Estadual do Oeste do Paraná for support and infrastructure during field campaigns. We also thanks the members of the Laboratório de Ictiologia, Ecologia e Biomonitoramento (LIEB), S. Pini and J. F. Neves for field assistance, the Laboratório de Ictiologia Universidade Federal do Rio Grande do Sul for help with species identification, the Y. Moretto for macroinvertebrate analysis, the Conselho Nacional de Desenvolvimento Científico e Tecnológico and Coordenação de Aperfeiçoamento de Pessoal de Nível Superior for a $\mathrm{PhD}$ scholarship (CNPq Proc. 152847/2016-2, CAPES Proc. 88887.363419/2019-00, to MPN), the Programa de Pós-Graduação em Biologia Animal/ UFRGS, L. Nash and L. Sivess for comments on the manuscript. P.K. gratefully acknowledges funding from the Royal Society (grant NAF\R2\180791).

\section{Declarations}

Conflict of interest The authors have no competing interests.

Open Access This article is licensed under a Creative Commons Attribution 4.0 International License, which permits use, sharing, adaptation, distribution and reproduction in any medium or format, as long as you give appropriate credit to the original author(s) and the source, provide a link to the Creative Commons licence, and indicate if changes were made. The images or other third party material in this article are included in the article's Creative Commons licence, unless indicated 
otherwise in a credit line to the material. If material is not included in the article's Creative Commons licence and your intended use is not permitted by statutory regulation or exceeds the permitted use, you will need to obtain permission directly from the copyright holder. To view a copy of this licence, visit http://creativecommons.org/licenses/by/4.0/.

\section{References}

Abell R, Thieme ML, Revenga C, Bryer M, Kottelat M, Bogutskaya N, Coad B, Mandrak N, Balderas SC, Bussing W, Stiassny MLJ, Skelton P, Allen GR, Unmack P, Naseka A, Ng R, Sindorf N, Robertson J, Armijo E, Higgins JV, Heibel TJ, Wikramanayake E, Olson D, López HL, Reis RE, Lundberg JG, Pérez MHS, Petry P (2008) Freshwater ecoregions of the world: a new map of biogeographic units for freshwater biodiversity conservation. Bioscience 58:403-414. https://doi.org/10.1641/B580507

Abilhoa V, Duboc LF (2007) A new species of the freshwater fish genus Astyanax (Ostariophysi: Characidae) from the rio Iguaçu basin, southeastern Brazil. Zootaxa 1587:43-52. http://doi.org/https://doi.org/10.11646/ zootaxa.1587.1.3

Abujanra F, Agostinho AA, Hahn NS (2009) Effects of the flood regime on the body condition of fish of different trophic guilds in the Upper Paraná River floodplain, Brazil. Braz J Biol 69:459-468. https://doi.org/10.1590/S151969842009000300003

Albrecht M, Gotelli NK (2001) Spatial and temporal niche partitioning in grassland ants. Oecologia 126:134-141. https://doi.org/10.1007/s004420000494

Alves GHZ, Cionek VM, Manetta GL, Pazianoto LHR, Benedito E (2020) Stable isotopes reveal niche segregation between native and nonnative Hoplias in a Neotropical floodplain. Ecol Freshw Fish. https://doi.org/10.1111/EFF. 12536

Anderson MJ (2001) A new method for non-parametric multivariate analysis of variance. Austral Ecol 26:32-46. https:// doi.org/10.1111/j.1442-9993.2001.01070.pp.x

Anderson MJ (2006) Distance based tests for homogeneity of multivariate dispersions. Biometrics 62:245-253. https:// doi.org/10.1111/j.1541-0420.2005.00440.x

Baldasso MC, Wolff LL, Neves MP, Delariva RL (2019) Ecomorphological variations and food supply drive trophic relationships in the fish fauna of a pristine neotropical stream. Environ Biol Fishes 102:783-800. https://doi.org/ 10.1007/s10641-019-00871-w

Baldo L, Riera JL, Tooming-Klunderud A, Albà MM, Salzburger W (2015) Gut microbiota dynamics during dietary shift in eastern African cichlid fishes. PLoS ONE 10:e127462. https://doi.org/10.1371/journal.pone. 0127462

Barros G, Zuanon J, Deus C (2017) Effects of species co-occurrence on the trophic-niche breadth of characids in Amazon forest streams. J Fish Biol 90:326-340. https:// doi.org/10.1111/jfb.13183
Bastos RF, Corrêa F, Winemiller KO, Garcia AM (2017) Are you what you eat? Effects of trophic discrimination factors on estimates of food assimilation and trophic position with a new estimation method. Ecol Indic 75:234-241. https:// doi.org/10.1016/j.ecolind.2016.12.007

Baumgartner G, Pavanelli CS, Baumgartner D, Bifi AG, Debona T, Frana VA (2012) Peixes do baixo rio Iguaçu. Editora da Universidade Estadual de Maringá-EDUEM, Maringá

Bicudo CEM, Bicudo RMT (1970) Algas de águas continentais brasileiras chave ilustrada para identificação de gêneros. Fundação Brasileira para o Desenvolvimento do Ensino de Ciências, São Paulo

Bivand RS, Pebesma E, Gomez-Rubio V (2013) Applied spatial data analysis with R, 2nd edn. Springer, New York

Bonato KO, Burress ED, Fialho CB (2017) Dietary differentiation in relation to mouth and tooth morphology of a neotropical characid fish community. Zool Anz 267:31-40. https://doi.org/10.1016/j.jcz.2017.01.003

Bonato KO, Burress ED, Fialho CB, Armbruster JW (2018) Resource partitioning among syntopic Characidae corroborated by gut content and stable isotope analyses. Hydrobiologia 805:311-324. https://doi.org/10.1007/s10750017-3314-0

Bowen SH, Lutz EV, Ahlgren MO (1995) Dietary protein and energy as determinants of food quality: trophic strategies compared. Ecology 76(3):899-907

Buchheister A, Latour RJ (2010) Turnover and fractionation of carbon and nitrogen stable isotopes in tissues of a migratory coastal predator summer flounder (Paralichthys dentatus). Can J Fish Aquat Sci 67:445-461. https://doi.org/ 10.1139/F09-196

Chase JM, Leibold MA (2003) Ecological niches - linking classical and contemporary approaches. University of Chicago, Chicago

Chesson P (2000) Mechanisms of maintenance of species diversity. Annu Rev Ecol Syst 31:343-366. https://doi.org/ 10.1146/annurev.ecolsys.31.1.343

Chou SC, Lyra A, Mourão C, Dereczynski C, Pilotto I, Gomes J, Bustamante J, Tavares P, Silva A, Rodrigues D, Campos D, Chagas D, Sueiro G, Siqueira G, Marengo J (2014) Assessment of climate change over South America under RCP 4.5 and 8.5 downscaling scenarios. Am J Clim Change 3:512-525. https://doi.org/10.4236/ajcc.2014. 35043

Correa SB, Winemiller KO (2014) Niche partitioning among frugivorous fishes in response to fluctuating resources in the Amazonian floodplain forest. Ecology 95:210-224. https://doi.org/10.1890/13-0393.1

Costa-Pereira R, Tavares LE, Camargo PB, Araújo MS (2017) Seasonal population and individual niche dynamics in a tetra fish in the Pantanal wetlands. Biotropica 49:531-538. https://doi.org/10.1111/btp.12434

Cucherousset J, Villéger S (2015) Quantifying the multiple facets of isotopic diversity: new metrics for stable isotope ecology. Ecol Ind 56:152-160. https://doi.org/10.1016/j. ecolind.2015.03.032

Delariva RL, Hahn NS, Kashiwaqui EA (2013) Diet and trophic structure of the fish fauna in a subtropical ecosystem: Impoundment effects. Neotrop Ichthyol 11:891-904. https://doi.org/10.1590/S1679-62252013000400017 
Delariva RL, Neves MP, Larentis C, Kliemann BCK, Baldasso MC, Wolff LL (2018) Fish fauna in forested and rural streams from an ecoregion of high endemism, lower Iguaçu River basin. Brazil Biota Neotrop 18:e20170459. https:// doi.org/10.1590/1676-0611-bn-2017-0459

Eigenmann CH (1911) New characins in the collection of the Carnegie Museum.

Eschmeyer WN, Fricke R, van der Laan R (2016) Catalog of fishes: genera, species, references [Internet]. California Academy of Science, San Francisco. http:// researcharchive.calacademy.org/research/ichthyology/ catalog/fishcatmain.asp

FIOCRUZ (2016) Pesquisa inédita mapeia mudanças do clima no Paraná, que ficará até $5,6^{\circ} \mathrm{C}$ mais quente [Internet]. Fundação Oswaldo Cruz, Minas Gerais. https://portal. fiocruz.br/noticia/pesquisa-inedita-mapeia-mudancas-doclima-no-parana-que-ficara-ate-56degc-mais-quente

Fox J, Weisberg S (2019) An $\{\mathrm{R}\}$ Companion to Applied Regression, Third Edition. Thousand Oaks CA: Sage. https://socialsciences.mcmaster.ca/jfox/Books/ Companion/

Garavello JC, Sampaio FAA (2010) Five new species of genus Astyanax Baird \& Girard, 1854 from Rio Iguaçu, Paraná, Brazil (Ostariophysi, Characiformes, Characidae). Braz J Biol 70:847-865. https://doi.org/10.1590/S151969842010000400016

Garcia AM, Claudino MC, Mont'Alverne R, Pereyra PER, Copertino M, Vieira JP, (2016) Temporal variability in assimilation of basal food sources by an omnivorous fish at Patos Lagoon Estuary revealed by stable isotopes (2010-2014). Mar Biol Res 13:98-107. https://doi.org/10. 1080/17451000.2016.1206939

Gerking SD (1994) Feeding ecology of fishes. Academic Press, San Diego, CA

German DP, Nagle BC, Villeda JM, Ruiz AM, Thomson AW, Balderas SC, Evans DH (2009) Evolution of herbivory in a carnivorous clade of minnows (Teleostei: Cyprinidae): effects on gut size and digestive physiology. Physiol Biochem Zool 83:1-18. https://doi.org/10.1086/648510

González-Bergonzoni I, Meerhoff M, Davidson TA, Teixeira-de Mello F, Baattrup-Pedersen A, Jeppesen E (2012) Metaanalysis shows a consistent and strong latitudinal pattern in fish omnivory across ecosystems. Ecosystems 15:492-503. https://doi.org/10.1007/s10021-012-9524-4

Gotelli NJ, Hart EM, Ellison AM (2015) EcoSimR: null model analysis for ecological data. $\mathrm{R}$ package version 0.1 .0

Grossman GD (1986) Food resources partitioning in a rocky intertidal fish assemblage. J Zool 1:317-355. https://doi. org/10.1111/j.1096-3642.1986.tb00642.x

Haluch CF, Abilhoa V (2005) Astyanax totae, a new characid species (Teleostei: Characidae) from the upper rio Iguaçu basin, southeastern Brazil. Neotrop Ichthyol 3:383-388. https://doi.org/10.1590/S1679-62252005000300005

Hart SP, Schreiber SJ, Levine JM (2016) How variation between individuals affects species coexistence. Ecol Lett 19:825-838. https://doi.org/10.1111/ele.12618

Hellawell JM, Abel R (1971) A rapid volumetric method for the analysis of the food of fishes. J Fish Biol 3:29-37. https:// doi.org/10.1111/j.1095-8649.1971.tb05903.x

Hoffman JC, Sierszen ME, Cotter AM (2015) Fish tissue lipid$\mathrm{C}$ : $\mathrm{N}$ relationships for correcting $\delta^{13} \mathrm{C}$ values and estimating lipid content in aquatic food-web studies. Rapid Commun Mass Spectrom 29:2069-2077. https://doi.org/ $10.1002 / \mathrm{rcm} .7367$

Holt RD, Polis GA (1997) A theoretical framework for intraguild predation. Am Nat 149:745-764. https://doi.org/10. 1086/286018

Hopkins JB III, Ferguson JM (2012) Estimating the diets of animals using stable isotopes and a comprehensive Bayesian mixing model. PLoS ONE 7:e28478. https://doi.org/ 10.1371/journal.pone.0028478

Hyslop EJ (1980) Stomach content analysis: a review of methods and their application. J Fish Biol 17:411-429. https:// doi.org/10.1111/j.1095-8649.1980.tb02775.x

Ingenito LF, Duboc LF (2014) A new species of Astyanax (Ostariophysi: Characiformes: Characidae) from the upper rio Iguaçu basin, southern Brazil. Neotrop Ichthyol 12:281-290. https://doi.org/10.1590/1982-0224-20130117

Ingram T, Svanbäck R, Kraft NJ, Kratina P, Southcott L, Schluter D (2012) Intraguild predation drives evolutionary niche shift in three spine stickleback. Evolution 66:1819-1832. https://doi.org/10.1111/j.1558-5646.2011. 01545.x

Jardine TD, Hunt RJ, Pusey BJ, Bunn SE (2011) A nonlethal sampling method for stable carbon and nitrogen isotope studies of tropical fishes. Mar Freshw Res 62:83-90. https://doi.org/10.1071/MF10211

Kambikambi MJ, Chakona A, Kadye WT (2019) The influence of diet composition and tissue type on the stable isotope incorporation patterns of a small-bodied southern African minnow Enteromius anoplus (Cypriniformes, Cyprinidae). Rapid Commun Mass Spectrom 33:613-623. https://doi. org/10.1002/rcm.8393

Kaymak N, Winemiller KO, Akin S, Altuner Z, Polat F, Dal T (2015) Stable isotope analysis reveal relative influences of seasonal variation and impoundment on assimilation of primary production sources by fish in the Upper Yesilirmak River, Turkey. Hydrobiologia 753:131-147. https://doi. org/10.1007/s10750-015-2201-9

Kelly LJ, Martínez del Rio C (2010) The fate of carbon in growing fish: an experimental study of isotopic routing. Physiol Biochem Zool 83:473-480. https://doi.org/10. 1086/649628

Köppen W (1936) Das geographische System der Klimate. In: Köppen W, Geiger R (eds) Handbuch der Klimato-logie. Gebrüder Borntraeger, Berlin, p 44

Kratina P, LeCraw RM, Ingram T, Anholt BR (2012) Stability and persistence of food webs with omnivory: Is there a general pattern? Ecosphere 3(6):50. https://doi.org/10. 1890/ES12-00121.1

Larentis C, Delariva RL, Gomes LC, Baumgartner D, Ramos IP, Sereia DADO (2016) Ichthyofauna of streams from the lower Iguaçu River basin, Paraná State. Brazil Biota Neotrop 16:e20150117. https://doi.org/10.1590/16760611-BN-2015-0117

Lisboa LK, da Silva ALL, Siegloch AE, Júnior JFG, Petrucio MM (2015) Temporal dynamics of allochthonous coarse particulate organic matter in a subtropical Atlantic rainforest Brazilian stream. Mar Freshw Res 66:674-680. https://doi.org/10.1071/MF14068 
Lowe-McConnell RH (1999) Estudos ecológicos de comunidades de peixes tropicais. Editora da Universidade de São Paulo-EDUSP, São Paulo, SP

McCutchan JH, Lewis WM, Kendall C, McGrath CC (2003) Variation in trophic shift for stable isotope ratios of carbon, nitrogen, and sulphur. Oikos 102:378-390

Mise FT, Fugi R, Pagotto JPA, Goulart E (2013) The coexistence of endemic species of Astyanax (Teleostei: Characidae) is propitiated by ecomorphological and trophic variations. Biota Neotrop 13:21-28. https://doi.org/ 10.1590/S1676-06032013000300001

MontAlverne R, Jardine TD, Pereyra PER, Oliveira MCLM, Medeiros RS, Sampaio LA, Tesses MB, Garcia AM (2016) Elemental turnover rates and isotopic discrimination in a euryhaline fish reared under different salinities: Implications for movement studies. J Exp Mar Bio Ecol 480:36-44. https://doi.org/10.1016/j.jembe.2016.03.021

Moore JW, Semmens BX (2008) Incorporating uncertainty and prior information into stable isotope mixing models. Ecol Lett 11:470-480. https://doi.org/10.1111/j.1461-0248. 2008.01163.x

Mugnai R, Nessimian JL, Baptista DF (2010) Manual de identificação de macroinvertebrados aquáticos do estado do Rio de Janeiro. Technical Books, Rio de Janeiro

Neres-Lima V, Brito EF, Krsulović FA, Detweiler AM, Hershey AE, Moulton TP (2016) High importance of autochthonous basal food source for the food web of a Brazilian tropical stream regardless of shading. Internat Rev Hydrobiol 101:132-142. https://doi.org/10.1002/iroh.201601851

Neves MP, Amorim JPA, Delariva RL (2018a) Influence of land use on the health of a detritivorous fish (Ancistrus mullerae) endemic to the Iguassu ecoregion: relationship between agricultural land use and severe histopathological alterations. Environ Sci Pollut Res Int 25:11670-11682. https://doi.org/10.1007/s11356-018-1283-0

Neves MP, Delariva RL, Wolff LL (2015) Diet and ecomorphological relationships of an endemic, species-poor fish assemblage in a stream in the Iguaçu National Park. Neotrop Ichthyol 13:245-254. https://doi.org/10.1590/19820224-20140124

Neves MP, Silva JC, Baumgartner D, Baumgartner G, Delariva RL (2018b) Is resource partitioning the key? The role of intra-interspecific variation in coexistence among five small endemic fish species (Characidae) in subtropical rivers. J Fish Biol 93:238-249. https://doi.org/10.1111/jfb. 13662

Nielsen JM, Clare EL, Hayden B, Brett MT, Kratina P (2018) Diet tracing in ecology: method comparison and selection. Methods Ecol Evol 9:278-291. https://doi.org/10.1111/ 2041-210X.12869

Oksanen J, Blanchet FG, Friendly M, Kindt R, Legendre P, McGlim D, Minchin PR, O'Hara RB, Simpson GL, Solymos P, Stevens MHH, Szoecs E, Wagner H (2019) The vegan package. Community Ecology Package. R package version 2.5-5. https://cran.r-project.org/web/packages/ vegan/index.html

OliveirMontAlverne MCLM, Sampaio LA, Tesser MB, Ramos LR, Garcia AM (2017) Elemental turnover rates and trophic discrimination in juvenile Lebranhe mullet Mugilliza under experimental conditions. J Fish Biol 91:1241-1249. https://doi.org/10.1111/jfb.13408
Parnell AC, Inger R, Bearhop S, Jackson AL (2010) Source partitioning using stable isotopes: coping with too much variation. PLoS ONE 5:e09672. https://doi.org/10.1371/ journal.pone.0009672

Pavanelli CS, Oliveira CAM (2009) A redescription of Astyanax gymnodontus (Eigenmann, 1911), new combination, a polymorphic characid fish from the rio Iguaçu basin, Brazil. Neotrop Ichthyol 7:569-578. https://doi.org/10.1590/ S1679-62252009000400003

Pebesma EJ, Bivand RS (2005) Classes and methods for spatial data in R. R News 5 2. https://cran.r-project.org/doc/ Rnews/

Pelster B, Wood CM, Speers-Roesch B, Driedzic WR, AlmeidaVal V, Val A (2015) Gut transport characteristics in herbivorous and carnivorous serrasalmid fish from ion-poor Rio Negro water. J Comp Physiol B 185:225-241. https:// doi.org/10.1007/s00360-014-0879-z

Pereira HM, Leadley PW, Proença V, Alkemade R, Scharlemann JP, Fernandez-Manjarrés JF, Araújo MB, Balvanera P, Biggs R, Cheung WWL, Chini L, Cooper HD, Gulman EL, Guénette S, Hurtt G, Huntington HP, Mace GM, Oberdorff T, Revenga C, Rodrigues P, Scholes RJ, Sumaila UR, Walpole M (2010) Scenarios for global biodiversity in the 21st century. Science 330:1496-1501. https://doi.org/ 10.1126/science. 1196624

Perkins DM, Durance I, Edwards FK, Grey J, Hildrew AG, Jackson M, Jones IJ, Lauridsen RB, Layer-Dobra K, Thompson MSA, Woodward G (2018) Bending the rules: exploitation of allochthonous resources by a top-predator modifies size-abundance scaling in stream food webs. Ecol Lett 21(12):1771-1780. https://doi.org/10.1111/ele.13147

Perry G, Pianka E (1997) Animal foraging: past, present and future. Trends Ecol Evol 12:360-364. https://doi.org/10. 1016/S0169-5347(97)01097-5

Phillips DL, Inger R, Bearhop S, Jackson AL, Moore JW, Parnell AC, Semmens BX, Ward EJ (2014) Best practices for use of stable isotope mixing models in food-web studies. Can J Zool 92:823-835. https://doi.org/10.1139/cjz-20140127

Pianka ER (1973) The structure of lizard communities. Annu Rev Ecol Syst 4:53-74

Pianka ER (1974) Niche overlap and diffuse competition. Proc Natl Acad Sci 71:2141-2145. https://doi.org/10.1073/ pnas.71.5.2141

Pimm SL (1982) Food webs. Chapman \& Hall, London

Pimm SL, Lawton JH (1978) On feeding on more than one trophic level. Nature 275:542. https://doi.org/10.1038/ $275542 \mathrm{a} 0$

Pimm SL, Lawton JH, Cohen JE (1991) Food web patterns and their consequences. Nature 350:669-674. https://doi.org/ 10.1038/350669a0

Pini SFR, Abelha MCF, Kashiwaqui EAL, Delariva RL, Makrakis S, Makrakis M (2019) Food resource partitioning among species of Astyanax (Characiformes: Characidae) in the Low Iguaçu River and tributaries. Brazil Neotrop Ichthyol 17:e190028. https://doi.org/10.1590/1982-0224-20190028

Polis GA, Myers CA, Holt RD (1989) The ecology and evolution of intraguild predation: potential competitors that eat each other. Annu Rev Ecol Syst 20:297-330 
Post DM, Takimoto G (2007) Proximate structural mechanisms for variation in food-chain length. Oikos 116:775-782. https://doi.org/10.1111/j.0030-1299.2007.15552.x

Pujarra S, Pandolfo A, Lourenço DK, Gurski FA, dosSantos APA, Moretto Y (2017) Distribution of benthic communities in relation to the environmental integrity of subtropical streams. Ecol Austral 27:482-491. https://doi.org/ 10.25260/EA.17.27.3.0.374

Quezada-Romegialli C, Jackson AL, Harrod C (2019) tRophicPosition: Bayesian trophic position calculation with stable isotopes. R package version 0.7.7. https://CRAN.Rproject.org/package $=$ tRophicPosition

Quirino BA, Carniatto N, Gaiotto JV, Fugi R (2015) Seasonal variation in the use of food resources by small fishes inhabiting the littoral zone in a Neotropical floodplain lake. Aquat Ecol 49:431-440. https://doi.org/10.1007/s10452015-9535-2

Quirino BA, Carniatto N, Guglielmetti R, Fugi R (2017) Changes in diet and niche breadth of a small fish species in response to the flood pulse in a Neotropical floodplain lake. Limnologica 62:126-131. https://doi.org/10.1016/j.limno. 2016.10.005

R Core Team (2019) R: a language and environment for statistical com-puting. R Foundation for Statistical Computing, Vienna, Austria. https://www.R-proje.ct.org/

Rossini BC, Oliveira CAM, de Melo FAG, Bertaco VA, de Astarloa JMD, Rosso JJ, Foresti F, Oliveira C (2016) Highlighting Astyanax species diversity through DNA barcoding. PLoS ONE 11:e0167203. https://doi.org/10. 1371/journal.pone.0167203

Rowlingson B, Diggle P (2017) Splancs: Spatial and space-time point pattern analysis. $\mathrm{R}$ package version 2:01-40

Ruiz-Cooley RI, Gerrodette T, Fiedler PC, Chivers SJ, Danil K, Ballance LT (2017) Temporal variation in pelagic food chain length in response to environmental change. Sci Adv 3:e1701140. https://doi.org/10.1126/sciadv.1701140

Schoener TW (1971) Theory of Feeding Strategies. Annu Rev Ecol Evol Syst 2:369-404

Schoener TW (1974) Resource partitioning in ecological communities. Science 185:27-39. https://doi.org/10.1126/ science.185.4145.27

Serra CR, Almeida EM, Guerreiro I, Santos R, Merrifield DL, Tavares F, Oliva-Teles A, Enes P (2019) Selection of carbohydrate-active probiotics from the gut of carnivorous fish fed plant-based diets. Sci Rep 9:6384. https://doi.org/ 10.1038/s41598-019-42716-7

Silva JC, Gubiani ÉA, Neves MP, Delariva RL (2017) Coexisting small fish species in lotic neotropical environments: evidence of trophic niche differentiation. Aquat Ecol 51:275-288. https://doi.org/10.1007/s10452-017-9616-5

Smith JA, Mazumder D, Suthers IM, Taylor MD (2013) To fit or not to fit: evaluating stable isotope mixing models using simulated mixing polygons. Methods Ecol Evol 47:612-618. https://doi.org/10.1111/2041-210X.12048

Soares SDA, Suarez YR, Fernandes WD, Tenório PMS, Delabie JHC, Antonialli-Junior WF (2013) Temporal variation in the composition of ant assemblages (Hymenoptera, Formicidae) on trees in the Pantanal floodplain, Mato Grosso do Sul, Brazil. Rev Bras Entomol 57:84-90. https:// doi.org/10.1590/S0085-56262013000100013
Stephens DW, Krebs JR (1986) Foraging theory. Princeton University Press, Princeton

Stock BC, Semmens BX (2016a) MixSIAR GUI User Manual. Version 3.1

Stock BC, Semmens BX (2016) Unifying error structures in commonly used biotracer mixing models. Ecology 97:2562-2569. https://doi.org/10.1002/ecy.1517

Terán GE, Benitez MF, Mirande JM (2020) Opening the Trojan horse: phylogeny of Astyanax, two new genera and resurrection of Psalidodon (Teleostei: Characidae). Zool J Linnean Soc, XX, pp 1-18

Tilman D (1990) Constraints and trade-offs: toward a predictive theory of competition and succession. Oikos 58:3-15. https://doi.org/10.2307/3565355

Tonin A, Gonçalves JF Jr, Bambi P, Couceiro SRM, Feitoza LAM, Fontana LE, Hamada N, Hepp LU, Lezan-Kowalczuk VG, Leite GFM, Lemes-Silva AL, Lisboa LK, Loureiro RC, Martins RT, Medeiros AO, Morais PB, Moretto Y, Oliveria PCA, Pereira EB, Ferreira LP, Pérez J, Petrucio MM, Reis DF, Rezende RS, Roque N, Santos LEP, Siegloch AE, Tonello G, Boyero L (2017) Plant litter dynamics in the forest-stream interface: precipitation is a major control across tropical biomes. Sci Rep 7:1-14. https://doi.org/10.1038/s41598-017-10576-8

Vazzoler AEAM (1996) Biologia da reprodução de peixes teleósteos: teoria e prática. Eduem, Maringá

Vergnon R, Dulvy NK, Freckleton RP (2009) Niches versus neutrality: uncovering the drivers of diversity in a speciesrich community. Ecol Lett 12:1079-1090. https://doi.org/ 10.1111/j.1461-0248.2009.01364.x

Villéger S, Novack-Gottshall PM, Mouillot D (2011) The multidimensionality of the niche reveals functional diversity changes in benthic marine biotas across geological time. Ecol Lett 14:561-568. https://doi.org/10.1111/j. 1461-0248.2011.01618.x

Walker RH, Kluender ER, Inebnit TE, Reid AS (2013) Differences in diet and feeding ecology of similar-sized spotted (Lepisosteus oculatus) and shortnose (Lepisosteus platostomus) gars during flooding of a south-eastern US river. Ecol Freshw Fish 22:617-625. https://doi.org/10. 1111/eff.12066

Winemiller KO, Pianka ER (1990) Organization in natural assemblages of desert lizards and tropical fishes. Ecol Monogr 60:27-55. https://doi.org/10.2307/1943025

Winemiller KO (1989) Patterns of variation in life history among South American fishes in seasonal environments. Oecologia 81:225-241

Wootton KL (2017) Omnivory and stability in freshwater habitats: Does theory match reality? Freshw Biol 62:821-832. https://doi.org/10.1111/fwb.12908

Wootton R (1998) Ecology of teleost fishes. Springer, Berlin

Zawadzki CH, Renesto E, Bini LM (1999) Genetic and morphometric analysis of three species of the genus Hypostomus Lacépède, 1803 (Osteichthyes: Loricariidae) from the Rio Iguaçu basin (Brazil). Rev Suisse Zool 106:91-105

Publisher's Note Springer Nature remains neutral with regard to jurisdictional claims in published maps and institutional affiliations. 